\title{
Political Power in Narrow Road to the Deep North: Between Asian Tyranny and Western Imperialism
}

\author{
Dr Tarek Musleh \\ Professor of English at Jadara University
}

\begin{abstract}
This paper deals with Edward Bond's attempt to dramatize a modern dilemma that is typical of our world: dictatorship is presented by two extreme regimes, one by some Asian ruthless dictators who blatantly abuse power, the other by the more sophisticated and destructive methods of Western imperialists who make subjects always enslaved and indebted to mysterious and psychological forces outside themselves. Bond is sharply critical of both regimes and shows that man is trapped without a real outlet. At times the play borders on didacticism when the writer gets carried away and openly criticizes those who abuse power in one way or the other. Furthermore, he schematizes characterization to draw his somewhat deterministic conclusions that early education may have the upper hand in shaping dictators. However, the play has a sharp insight into the nature of violence and man's potentiality for ultimate evil, a visionary outlook that is quite rare, and is strongly related to the conflict between the East and the West.
\end{abstract}

Generally speaking, violence is associated with unhealthy situations. People resort to violence because they fail to put their world in order through peaceful means, or because they themselves are sick and resort to violence as an expression of some sort of paranoia, usually as a result of a troubled childhood or repressive circumstances. 'Injustice' is often the law of nature; perfection is outside human sphere. Man throughout history has been moving towards 'perfecting' life but with more failures than successes, especially in the political arena. Modern humans are just beginning to realize themselves in the huge and indifferent universe. Writers in particular are hypersensitive about this aspect of injustice and they try by hook or by crook to suggest solutions for the ruthless conditions that the majority of people are suffering from.

Edward Bond has adopted Marxism as a way to achieve the classless society which many socialists have been dreaming of. Marx himself has predicted that capitalism would sooner or later be abolished and the proletariat would eventually triumph. (Marx and Engels, The Modern Tradition, 323) However, so far, these predictions have unequivocally proven to be 'unrealistic', to say the least. In his plays Bond is 'obsessed' with violence to demonstrate that the society which is based on classes and injustice is bound to resort to some form of self-destruction because of the very contradictory nature of its existence. He reiterates:

A competitive society must destroy itself. There is no alternative, because this is the whole dialectic of violence - I threaten you, you threaten me, and finally you have to carry out your threats, otherwise there is no credence behind them. And also because aggression creates fear and this leads to more violence and this has an escalation of its own. So that if society goes on as it's going on now, it will destroy itself. Not will it, could it, might it - it will. ('Drama and the Dialects of Violence', 31)

He further claims to write about violence ' as naturally as Jane Austen wrote about manners. (Preface to King Lear, 11)

This idea of violence is fully demonstrated in Narrow Road to the Deep North which dramatizes a problem that is typical of our time in many parts of the world and reminiscent of the two World Wars and the constant threat of nuclear wars and the arms race. He visualizes a world ruled by ruthless dictators and vicious lunatics who are prepared to do anything to seize power. Despite the Brechtian alienation effects of choosing an almost timeless and exotic oriental atmosphere, violence has a sharp reality of its own and dominates everything. The following passage is typical of the whole play and reminiscent of some third world countries in our time: 
He's imprisoned innocent women, orphaned children, made the men soldiers, and killed them. His city is hell, ruled by atrocity. I could put up with that if I could still hope. But how can I hope if he destroys religion? He knew the pot was sacred. Of course, that's only a symbol, but we need symbols to protect us from ourselves. If he destroys them, there's no future. A fool destroys men but a fanatic destroys their hope - and he's a fanatic...(Narrow Road, 193)

It is implied that early education is vital in producing a healthy society controlled by 'rational' people and that if one is not favored with enough care, especially in childhood, violence becomes the only resort to express man's dormant and unlimited sense of megalomania.

Shogo, The ruthless tyrant, was abandoned in childhood by his parents because of poverty; had he been picked up by Basho, the old and irresponsible poet, he would not have become that vicious tyrant. As it is he has developed a Hitler like government where even high officers are threatened by constant fear of being liquidated:

Prime Minister. The Chief Inspector was killed today. Last week it was the Chief Fire Officer, the Chief Civil Servant and the Under-Chief Civil Servant. When he goes out he makes all the government officers stand round him. If it goes on like this we'll all be killed. (Narrow Road, 193)

On the other hand, had Basho accepted the young priest Kiro as his disciple the latter might not have despaired and committed suicide. The real villain in the play is this escapist poet who abandons the world and lives in abstraction rather than in reality. Instead of seeking enlightenment in some vague area of the deep north he should confront his own reality and act responsibly. Bond is unembarrassed to declare in the age of modernism when 'art for art's sake' is a dominant theory that literature should be clearly committed to promote a particular cause related to his own dream of the classless society; for him the very existence of art depends on the mission which it is expected to adopt: 'In an ideal society Basho would have picked that baby up, gone off the stage and there would have been no necessity for a play.' ('Rationalism, Realism and Radical Solutions', 160) Such a statement by Bond is highly extreme. Art can exist in any society whether ideal or not. Certainly conflict is the spirit of action, but no matter how ideal a society is conflict is there to motivate action. Conflict is not restricted to 'violent' societies but it may be related to all types of social life. Moreover, spiritual and internal conflict, which is more effective, is concomitant to the very nature of humans even if their material situation is satisfactory.

Bond concentrates on early education as a safeguard for peaceful rule. However, if we digress a little and resort to reality we find that many dictators have had that chance of good care in all the stages of their life, nonetheless, they are vicious and rule by the sheer logic of authority on the basis of 'power corrupts'. Perhaps the complexity of human nature is far more intricate than just to account for a stage in man's life; actually it is difficult to predict with any certainty the line of development of any human being. Recently scientists have been preoccupied with the 'miraculous' results of cloning in the world of animals. In theory it is possible to 'create' a so-called perfect human being in terms of color, beauty, size, etc., but it is difficult to predict the nature of this creature concerning temperament, philosophy, inclination and whether he/she is going to be religious, pessimistic, pacifist, violent, etc. Man's life and development is a mystery which cannot all the time be accounted for by circumstances.

Shogo's way depends on physical enslavement and sheer violence if necessary. By contrast, the British imperialists, who are brought by Basho, the Commodore and his so-called sister Georgina, employ a more sophisticated psychological method of a repressive morality, using the last emperor's child as their puppet. Georgina directly outlines her policy of imposing guilt on people which is a more successful political weapon than outright violence:

Georgina: Well, Shogo ruled by atrocity ... It didn't work, because it left people free to judge him. They said: he makes us suffer and that's wrong. He calls it law and order, but we say it's crime against us - and that's why they threw spears at him. So instead of atrocity I use morality. I persuade people - in their hearts - that they are sin, and that they have evil thoughts, and that they're greedy and violent and destructive, and - more than anything else - that their bodies must be hidden, and that sex is nasty and corrupting and must be secret. When they believe all threat they do what they're told, they don't judge you - they feel guilty themselves and accept that you have the right to judge them. That's how I run the city: the missions and churches and bishops and magistrates and politicians and papers will tell people they are sin and must be kept in order. If the devil didn't exist it would be necessary to invent him. I learned all this from my Scottish nanny. She taught our Prime Minister, the Queen, the Leader of the Opposition, and everyone else who matters. They all learned politics across her knee. (Narrow Road, 208) 
Certainly creating guilt systematically is bound to develop an unsettled and violent human nature with far more disastrous consequences. Ironically Georgina becomes her own victim of a burdened consciousness with guilt ('people who raise ghosts become haunted') partly because of her inhuman methods and partly because she causes the death of five children when she refuses to identify the emperor's son, and eventually she goes mad. In this way the writer concludes that a sick and unjust society creates violence and dictatorship which will lead to the collapse of the whole community.

The confusion, despair and suicide of Kiro are also symbolic of a sick society that affects the life of individuals who are not directly concerned with politics. The drowning man at the end of the play who, through his own efforts, saves himself is the only positive sign which 'allegorizes' the idea that despite all the mess and chaos of our present world there is still some hope, no matter how slight, for a solution: the 'sinking ship' may have some potential of rescuing itself through some floating 'rats'. However, this conclusion is weak because the man is not fully realized as a character but he is there for the scheme of the play and to be contrasted with Kiro whose self-indulgence prevents him from observing outside reality and hearing the man's cries for help.

Bond throughout the play and his other works concentrates on the Marxist idea that it is social life that should be given top priority and that the individual consciousness is exclusively shaped by social forces:

Human consciousness is not an innate quality that creates itself. We have an innate capacity for consciousness. How we become conscious is largely decided by our society and its institutions the family, schools, courts, media and so forth - and by the organization and practice of our work, the means by which we live. Human consciousness is a creation of society and takes historical forms. The nature of human consciousness at any time is a consequence of the particular society in which it is created. ('Introduction' to The Bundle, 123)

He approaches individuals in an almost deterministic way viewing them at the mercy of ruthless circumstances that they have little control over.

True, Shogo may have become a different man if he had more favorable circumstances, but he is and should be viewed as fully responsible for his atrocity regardless of his upbringing. Similarly, Kiro may not have despaired if Basho had accepted him as his disciple, but this is not enough justification for suicide; otherwise most people are justifiable to 'deviate'. It is clear that individualism for Bond has no role in shaping our world and society has the upper hand in manipulating life; he also thinks of rationalism as the outlet for all human problems. However, a critical survey of all the philosophical schools of thought will prove that there is not any panacea for any human issue, and a variety of opinions on the subject is perhaps the safest approach. Humans are not only a social instrument and hence their responsibility. Rationalism is a good approach but we have to account as well for other problems including viewing man as 'evil', unpredictable, egoistic, ambitious, mysterious and highly uncontrollable. The religious story of a disobedient Adam symbolizes man's intrinsic desire not to heed any authority not even that of his Creator. With a lot of caution one may suggest 'sublimation' as a way to curb the hidden egoistic forces within man.

Certainly writers have the right to dramatize any idea in their work providing they do not reveal their obsession and over-enthusiasm to clearly demonstrate their ideology. Otherwise they run the risk of becoming didactic and this is usually done at the expense of the artistic quality of their work. Throughout his plays, Bond is heedless of this idea of the ideal society and one feels that he is a kind of a utopian writer, though he denies the charge in one interview, (Gambit, 9) or a dreamer obsessed with achieving the classless 'perfect' society. This obsession makes him at times appear didactic as when he 'decides' or 'imposes' the course of action for most of the characters of Narrow Road to the Deep North in a schematic way. Thus Shogo has to become a tyrant, Georgina should go mad, Kiro must commit suicide and Basho is to continue his shameful role (even in the next play The Bundle, a rewriting of Narrow Road to the Deep North) as a parasite and opportunist, simply because they are surrounded by a sick, capitalist and self-destructive society. Moreover Georgina's speech (quoted above) about her methods of ruling colonized people is not only direct but openly didactic; the writer wants to show the mentality of a sick imperialist obsessed with paralyzing the consciousness of people and is apparently and ironically delighted at her so-called success: everything is clear and schematized and there is no real complexity of the situation. Neither are we shown dramatically how religion, as visualized from a typical Marxist viewpoint, is poisoning and crippling the consciousness of people. Surely, we need more demonstration than just statements by a leader who is not quite balanced and is on the verge of madness. 
One the whole one can admire the commitment of a writer to equality and the ideal society, though this may never be realized in reality. There is no doubt that 'Bond has exposed the corruption and insanity of a world founded on capitalism'. (Hurst, 4) 10) However, life has taught us to be careful about any forceful or radical 'scheme' of action whether in fact or fiction: Initially it may lead to authoritarianism and the police state as it did in some socialist countries; secondly it may make characters like puppets performing the role designed for them from above rather than springing from internal development.

It seems that the greatness of literature, and this applies to English literature in general and Shakespeare in particular, is largely related to creating powerful individuals torn from within by so many mysterious forces that sometimes cannot be decided or determined. By contrast the 'naturalist' tradition has created weak characters, almost like puppets in some cases, enacting the life of individuals under powerful circumstances that they cannot manipulate. Any writer who is obsessed with an idea usually produces characters whose function appears to be schematizing one's own ideology. Most writers in the West are skeptic about any 'panacea' because of the complexity of the present circumstances of our modern life and of a human 'spiritual' nature that is always restless regardless of material conditions. English literature is predominantly on the side of individualized and powerful characterization. One may conclude with some reservation that Had Bond modified his obsession with the 'unrealistic' idea of the classless society he might have produced greater and more complex characterization with far more satisfactory results!

\section{REFERENCES}

Bond, Edward, 'Drama and the Dialectics of violence': Interview in Theatre Quarterly, Vol. II no.5 (January - March 1972)

Bond, Preface to Lear, (London: Methuen 1971)

Bond, Interview in Gambit, 5, no. 17 (1970)

Bond, Narrow Road to the Deep North. (London, Methuen: 1968)

Bond, 'Rationalism, Realism and Radical solutions ', Gambit, 4, no. 13 (1971)

Bond, ' Introduction ' to The Bundle, (London: Methuen 1978)

Hurst, D. L., Edward Bond, (Macmillan: 1985)

Marx, K. \& Engels, F., 'Social Reality as Class Struggle' in The Mdoern Tradition, ed. R. Ellmann \& C. Feidilson, (New York: Oxford University Press, 1977)

\section{Bibliography (Edward Bond)}

"Uniformed edition", 8 volumes by Methuen, London

vol. 1 (1977): Author's note: On Violence; Saved, Early morning; Pope's Wedding

vol. 2 (1978): Introduction; Preface to Lear; Lear; The Sea; Narrow Road to The Deep North, Black Mass; Passion

vol. 3 (1987): Four Pieces; Introduction to Bingo, Bingo; Introduction to The Fool; The Fool; Clare Poems; The Woman; Poems, Stories and Essays for The Woman; Author's note; Stone

vol. 4 (1992): The Worlds; The Activists Papers; Restoration; Restoration Poems and Stories; Summer; Summer Poems

vol. 5 (1996): Human Cannon, The Bundle; In the Company of Men; Jackets

vol. 6 (1998): Choruses from After the Assassinations; War Plays; Commentary on the War Plays

vol. 7 (2003): The Cap; The Crime of the Twenty-first Century; Olly's Prison; Notes on Imagination; Coffee; The Swing; Derek; Fables and Stories

vol. 8 (2006): Born, People, Chair, Existence, The Under Room

Other plays, by Methuen, London

At the Inland Sea (1997)

Eleven Vests with Tuesday (1997)

The Children with Have I None (2001)

Lear, Student Edition, with Commentary and Notes by Patricia Hern (1983)

Saved, Student Edition, with Commentary and Notes by David Davis (2008) 
Olly's Prison, stage and TV version (1993)

[edit] Selected theoretical writings

The Activists Papers (1980) in Plays 4, London, Methuen, 1992

A Note on Dramatic Method (1977), in: The Bundle, London, Methuen, 1978

Commentary on The War Plays (1991) in Plays 6, London, Methuen, 1998

The Dramatic Child, (1992), in Tuesday, London, Methuen, 1992

Drama Devices, ( 2004), in David Davis (ed.): Edward Bond and the Dramatic Child, Edward Bond's Plays for Young People, London, Trentham Books, 2005

The Hidden Plot Notes on Theatre and the State, London, Methuen, 2000

Introduction, for The Fool, in Plays 3, London, Methuen, 1987

Notes on Post-modernism (1989) in: Plays 5, London, Methuen, 1996

Notes on Imagination, in: Coffee, London, Methuen, 1995

"Something of Myself" (2004), in David Davis (ed.): Edward Bond and the Dramatic Child, Edward Bond's Plays for Young People, London, Trentham Books, 2005

\section{AUTHOR's BIOGRAPHY}

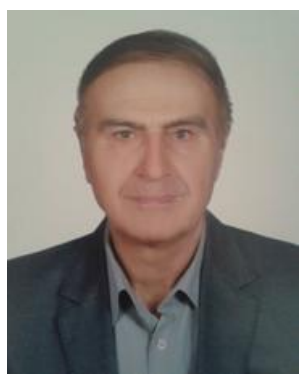

Dr Tarek Musleh, is a professor of English at Jadara University. He has published a number of papers mostly on fiction and a book entitled English Fiction: From Defoe to Golding 